2015-01-02

\title{
Phylogenetic analysis of rhodolith formation in the Corallinales (Rhodophyta)
}

\section{Hernandez-Kantun, JJ}

http://hdl.handle.net/10026.1/3903

\subsection{0/09670262.2014.984347}

European Journal of Phycology

Informa UK Limited

All content in PEARL is protected by copyright law. Author manuscripts are made available in accordance with publisher policies. Please cite only the published version using the details provided on the item record or document. In the absence of an open licence (e.g. Creative Commons), permissions for further reuse of content should be sought from the publisher or author. 
This article was downloaded by: [University of Plymouth]

On: 12 May 2015, At: 06:56

Publisher: Taylor \& Francis

Informa Ltd Registered in England and Wales Registered Number: 1072954 Registered office: Mortimer House, 37-41 Mortimer Street, London W1T 3J H, UK

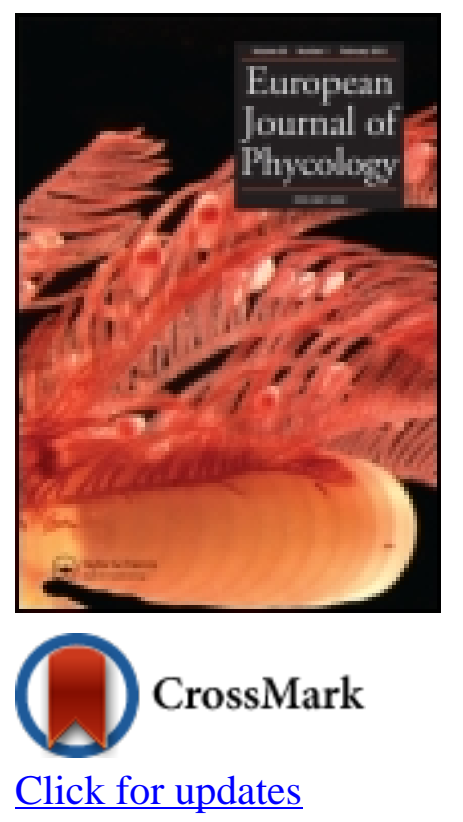

\title{
European J ournal of Phycology
}

Publication details, including instructions for authors and subscription information: http:// www. tandfonline.com/loi/tejp20

\section{Phylogenetic analysis of rhodolith formation in the Corallinales (Rhodophyta)}

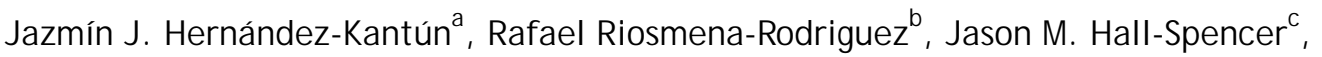 \\ Viviana Peña ${ }^{\text {def }}$, Christine A. Maggs ${ }^{9} \&$ Fabio Rindi ${ }^{\text {ah }}$ \\ ${ }^{a}$ Martin Ryan Institute, National University of Ireland, Galway, Ireland \\ ${ }^{\text {b }}$ Departamento de Biología Marina, Universidad de Baja California Sur (UABCS) Apartado \\ postal 19-B, km. 5. 5 Carretera al sur, La Paz, B.C.S. 23080, México \\ ' School of Marine Science and Engineering, Plymouth University, PL4 8AA, UK \\ d BIOCOST Research Group, Universidade da Coruña, Campus de A Zapateira, S/ N, 15071, \\ A Coruña, Spain \\ e UMR 7205 ISYEB CNRS, MNHN, UPMC, EPHE, Equipe Exploration, Espèces et Evolution, \\ Institut de Systématique, Evolution, Biodiversité, Muséum National d'Histoire Naturelle, \\ case postale № 39, 57 rue Cuvier, 75231, Paris, France \\ ${ }^{f}$ Phycology Research Group, Ghent University, Krijgslaan 281, Building S8, 9000, Ghent, \\ Belgium \\ ${ }^{9}$ School of Biological Sciences, The Queen's University of Belfast, 97 Lisburn Road, \\ Belfast BT9 7BL, Northern Ireland \\ ${ }^{\mathrm{h}}$ Dipartimento di Scienze della Vita e dell'Ambiente, Università Politecnica delle \\ Marche, Via Brecce Bianche, 60131 Ancona, Italy \\ Published online: 16 Dec 2014.
}

To cite this article: J azmín J. Hernández-Kantún, Rafael Riosmena-Rodriguez, J ason M. Hall-Spencer, Viviana Peña, Christine A. Maggs \& Fabio Rindi (2015) Phylogenetic analysis of rhodolith formation in the Corallinales (Rhodophyta), European J ournal of Phycology, 50:1, 46-61, DOI: 10.1080/09670262.2014.984347

To link to this article: http:// dx.doi.org/10.1080/09670262.2014.984347

\section{PLEASE SCROLL DOWN FOR ARTICLE}

Taylor \& Francis makes every effort to ensure the accuracy of all the information (the "Content") contained in the publications on our platform. However, Taylor \& Francis, our agents, and our licensors make no representations or warranties whatsoever as to the accuracy, completeness, or suitability for any purpose of the Content. Any opinions and views expressed in this publication are the opinions and views of the authors, and are not the views of or endorsed by Taylor \& Francis. The accuracy of the Content should not be relied upon and should be independently verified with primary sources of information. Taylor and Francis shall not be liable for any losses, actions, claims, proceedings, demands, costs, expenses, damages, and other liabilities whatsoever or howsoever caused arising directly or indirectly in connection with, in relation to or arising out of the use of the Content.

This article may be used for research, teaching, and private study purposes. Any substantial or systematic reproduction, redistribution, reselling, loan, sub-licensing, systematic supply, or distribution in any form to anyone is expressly forbidden. Terms \& Conditions of access and use can be found at http:// www.tandfonline.com/page/terms-and-conditions 


\title{
Phylogenetic analysis of rhodolith formation in the Corallinales (Rhodophyta)
}

\section{JAZMÍN J. HERNÁNDEZ-KANTÚN ${ }^{1 *}$, RAFAEL RIOSMENA-RODRIGUEZ ${ }^{2}$, JASON M. HALL- SPENCER $^{3}$, VIVIANA PEÑA ${ }^{4,5,6}$, CHRISTINE A. MAGGS $^{7}$ AND FABIO RINDI ${ }^{1,8}$}

\author{
${ }^{1}$ Martin Ryan Institute, National University of Ireland, Galway, Ireland \\ ${ }^{2}$ Departamento de Biología Marina, Universidad de Baja California Sur (UABCS) Apartado postal 19-B, km. 5.5 Carretera al \\ sur, La Paz, B.C.S. 23080, México \\ ${ }^{3}$ School of Marine Science and Engineering, Plymouth University, PL4 8AA, UK \\ ${ }^{4}$ BIOCOST Research Group, Universidade da Coruña, Campus de A Zapateira, S/N, 15071, A Coruña, Spain \\ ${ }^{5}$ UMR 7205 ISYEB CNRS, MNHN, UPMC, EPHE, Equipe Exploration, Espèces et Evolution, Institut de Systématique, \\ Evolution, Biodiversité, Muséum National d'Histoire Naturelle, case postale $n^{\circ} 39,57$ rue Cuvier, 75231, Paris, France \\ ${ }^{6}$ Phycology Research Group, Ghent University, Krijgslaan 281, Building S8, 9000, Ghent, Belgium \\ ${ }^{7}$ School of Biological Sciences, The Queen's University of Belfast, 97 Lisburn Road, Belfast BT9 7BL, Northern Ireland \\ ${ }^{8}$ Dipartimento di Scienze della Vita e dell'Ambiente, Università Politecnica delle Marche, Via Brecce Bianche, 60131 Ancona, Italy
}

(Received 22 December 2012; revised 28 July 2014; accepted 13 August 2014)

\begin{abstract}
Although the ecological importance of rhodolith (maerl, free-living coralline algae) beds is well-known, rhodolith-forming species have been neglected in molecular phylogenetic studies. This is the first molecular systematic study aimed at understanding whether the rhodolith habit is a fixed feature in lineages and determining the relationship (phylogenetic vs. environmental) between rhodolith and crustose habits. Phylogenetic relationships of rhodolith-forming species and encrusting coralline algae at generic and species levels were analysed using SSU rDNA and $p s b$ A sequences. Extensive sampling in the European North Atlantic, Pacific and Caribbean Mexico of Phymatolithon, Lithothamnion, Lithophyllum and Neogoniolithon taxa forming rhodoliths and crusts was accompanied by examination of type or topotype material. Phylogenetic reconstruction showed that Neogoniolithon contained a monophyletic group of rhodolith-forming species whereas other rhodolith-formers were closely related to encrusting forms in the genera Phymatolithon, Lithothamnion, Mesophyllum, Hydrolithon, Spongites and Sporolithon. DNA analysis showed that the crust-forming Lithophyllum cf. incrustans/dentatum also forms rhodoliths with a stone nucleus that occur on rocky shores. In contrast, species that form beds of non-nucleate rhodoliths (e.g. Neogoniolithon spectabile, N. strictum, Lithophyllum cf. incrustans/dentatum or sp. 1 and Phymatolithon calcareum) rarely form crusts. The rhodolith habit cannot be used to delimit species for taxonomic or identification purposes. Extensive taxonomic revision will be required to deal with problems such as the position of specimens identified as Lithophyllum margaritae in two unrelated lineages.
\end{abstract}

Key words: cryptic species, Lithophyllum, maerl, Phymatolithon, psbA, rhodolith, SSU rDNA, synapomorphy

\section{Introduction}

Coralline red algae (subclass Corallinophycidae, orders Corallinales and Sporolithales) include attached forms (encrusting thalli and erect segmented thalli) and unattached growths called rhodoliths, which may develop around a core of shell or stone or as a branched system without a core (Irvine \& Chamberlain, 1994; Harvey \& Woelkerling, 2007). Rhodolith beds occur worldwide in the euphotic zone and can form extensive habitats under suitable conditions (Foster, 2001). In Europe, unattached

Correspondence to: Jazmín J. Hernández-Kantún.

E-mail: jaz1083@gmail.com.

*Present address: Botany Department, National Museum of Natural History, Smithsonian Institution, Washington, DC. coralline seaweeds that lack a non-coralline core are known as maerl. The European Union, through the Habitats Directive (92/43/EEC), protects maerl beds as they have high associated diversity and are sensitive to anthropogenic disturbance (Kamenos et al., 2004; Hall-Spencer et al., 2006, 2010; Peña \& Bárbara, 2008; Rix et al., 2012; Teichert et al., 2012; Peña et al., 2014a).

Despite the ecological importance of rhodolith beds, examination of molecular phylogenies of coralline algae indicates that rhodoliths have been severely under-represented in these studies (Bailey \& Chapman, 1996; 1998; Harvey et al., 2003; Vidal et al., 2008; Bailey et al., 2004; Le Gall \& Saunders, 2007; Broom et al., 2008; Walker et al., 2009; Le Gall et al., 2010; Bittner et al., 2011; Kato et al., 2011, 2013; Gabrielson et al., 2011; Bahía et al., 2014). In 
13 articles investigating molecular systematics of coralline algae, in which hundreds of specimens were analysed, only one sample was labelled as a rhodolith (Broom et al., 2008). Phylogenetic reconstructions that fail to include rhodoliths omit an important aspect of the evolution of the coralline algae. Rhodoliths occur in the orders Sporolithales (genus Sporolithon) and Corallinales (Lithophyllum, Neogoniolithon, Spongites, Porolithon, Hydrolithon, Phymatolithon, Lithothamnion and Mesophyllum) (Johansen, 1981; Irvine \& Chamberlain, 1994; Harvey \& Woelkerling, 2007; Peña et al., 2011). The rhodolith habit may have existed in a common ancestor of the Sporolithales and Corallinales or could have arisen independently multiple times in these two orders, which include many taxa that do not form rhodoliths (Johansen, 1981). The fossil record supports the former idea as Sporolithon rhodoliths existed 113-125 million years ago, around the time of the estimated divergence of Corallinales and Sporolithales (Tomás et al., 2007; Aguirre et al., 2010). Thus the ability to form rhodoliths appeared early in the evolution of these two orders, possibly in a hypothetical common ancestor, and is only observed in few genera in both Corallinales and Sporolithales at present (Johansen, 1981; Irvine \& Chamberlain, 1994; Harvey \& Woelkerling, 2007; Peña et al., 2011).

The identification of coralline algae is historically complicated by their morphological plasticity, the challenges of anatomical examination, and imprecise taxonomic descriptions (Woelkerling, 1988). Given these difficulties, coralline algal researchers now combine examination of type material and morphologically concordant material from type localities (e.g. topotypes) using DNA sequences or morphology to verify names (Gabrielson et al., 2011; Hind et al., 2014). In the present study, type material of rhodolith-forming species and/or other morphologically similar material from type localities was analysed using scanning electron microscopy (SEM) and reproductive information.

The poor representation of rhodoliths in molecular phylogenetic analyses and misidentifications has left some unanswered questions concerning the relationships between rhodoliths and the encrusting habit. In Lithophyllum, Phymatolithon and Mesophyllum, the formation of rhodoliths or crust morphologies has been used to separate species (Irvine \& Chamberlain, 1994; Riosmena-Rodriguez et al., 1999; Bressan \& Babbini, 2003). In Brittany, Lithothamnion corallioides (P.L. Crouan \& H.M. Crouan) P.L Crouan \& H.M. Crouan and Phymatolithon calcareum (Pallas) Adey \& McKibbin form both unattached and encrusting thalli (Mendoza \& Cabioch, 1998), whereas in the British Isles L. corallioides occurs as maerl and occasionally as crusts, and P. calcareum has only been found unattached (Irvine \& Chamberlain, 1994).
Conversely, in the Mediterranean, studies of $P$. calcareum have reported both gametophytes and tetrasporophytes forming both rhodoliths and crusts (Bressan \& Babbini, 2003); this has also been reported for Alaska (Konar et al., 2006). To date, molecular records of both life-history phases (gametophyte vs. tetrasporophyte) have been obtained for $P$. calcareum. Gametophytes of $P$. calcareum have been reported as encrusting forms growing on gravel, dead rhodoliths and pebbles from maerl beds in Brittany, whereas the tetrasporangial phase has been frequently observed as maerl along the Atlantic European coast (complete list of sites in Peña et al., 2014b).

The rhodolith habit of coralline algae has been used to characterize species and life-history stages, nevertheless its value as a synapomorphy versus convergence has never been analysed. This raises the question as to whether the rhodolith habit is a synapomorphy for particular lineages (defined as a shared derived feature of historical relatedness; Patterson, 1988) or whether the formation of rhodoliths is an example of convergence as an occasional response to environmental conditions. The use of synapomorphic key features to distinguish or characterize genetic lineages in seaweeds is exemplified by Verbruggen \& Kooistra (2004), who distinguished five lineages of Halimeda (Chlorophyta) with particular ecological and morphological features. This type of analysis has never been attempted for coralline red algae.

Here, we included a large number of rhodolith samples from many taxa to improve our understanding of the relationships between rhodolith-forming and encrusting coralline algae, particularly focusing on (1) the phylogenetic relationships between rhodolith-forming species and encrusting taxa within genera, (2) possible conspecificity of rhodoliths and encrusting algae, and (3) whether habit (rhodolith vs crust) is related to the life-history phase (gametophyte/ sporophyte). We also examine the occurrence of cryptic species within rhodolith-forming taxa and highlight taxonomic problems. When possible, we used sequences obtained from type material or other specimens from the type locality (e.g. topotype), in order to link Linnaean species names to molecular clades.

\section{Materials and methods}

\section{Taxon selection and sample collection}

We obtained a large number of rhodolith-forming samples and encrusting specimens of coralline algae from many taxa, including both sporophytes and gametophytes. Samples were collected primarily from Western Europe (Spain, France, Ireland and UK), the Mexican Caribbean and the Gulf of California (Table 1). Sampling sites included type localities of the following rhodolith-forming species: Bay of Brest, France (Lithothamnion corallioides, Crouan \& Crouan, 1867); Ría de Arousa, Spain (Mesophyllum sphaericum, Peña et al., 2011); Ballynakill Harbour, Galway, Ireland 
Table 1. Collection information and GenBank accession number for specimens used in the present study.

\begin{tabular}{llc}
\hline \hline $\begin{array}{l}\text { Family/species } \\
\text { (specimen code) }\end{array}$ & Collection information & GenBank accession \\
\hline
\end{tabular}

\section{Corallinaceae}

Amphiroa rigida (E96)

Lithophyllum byssoides (E72)

L. byssoides (E150)

Lithophyllum sp. 1 (E132)

Lithophyllum sp. 1 (E35)

Lithophyllum sp. 1 (E69)

Lithophyllum sp. 1 (E231)

Lithophyllum sp. 1 (E276)

Lithophyllum sp. 1 (E137)

Lithophyllum sp. 1 (E27)

Lithophyllum sp. 1 (E25)

Lithophyllum sp. 1 (E309)

Lithophyllum sp. 2 (E149)

Lithophyllum sp. 3 (E153)

Lithophyllum sp. 3 (E324)

Lithophyllum sp. 3 (E322)

Lithophyllum sp. 3 (E211)

L. margaritae (E68)

L. margaritae (E57)

Neogoniolithon brassica-

florida (E151)

N. spectabile (E93)

N. strictum (E100)

\section{Hapalidiaceae}

Lithothamnion corallioides (E139)

L. glaciale (E42)

L. muelleri (E63)

Mesophyllum engelhartii (E67)

M. erubescens (E36)

M. lichenoides (E43)

M. sphaericum (E73)

Phymatolithon calcareum (E160)

P. lenormandii (E16)

Phymatolithon sp. 1 (E31)
Mahahual, El Faro, Caribbean, México. Subtidal, 30 cm. 13 Jun 2009. Collectors: A. Sanchez and J. Hernandez

San Pedro de Cirro, A Coruña, Spain. Intertidal. 24 Apr 2010. Collectors: V. Peña and J. Hernandez

Isla Tarifa, Cadiz, Spain. Intertidal. 15 Sept 2009. Collector: R. Bermejo

Marseille, France, Code QUB Med 6. 18 November 2004. Collector: GALW15735 F. Mineur

Ardgroom, Co. Cork, Ireland. 17 Aug 2007. Collector: J. Nunn. GALW15771

Kingstown Bay, Co. Galway, Ireland. Subtidal. 22 Feb 1999. Collector: J. Hall-Spencer

Roaringwater Bay, Co. Cork. Subtidal. 1 July 1996. Collector: H. GALW13587 Fazakerley

Carna, Co. Galway, Ireland. Subtidal 3 m depth. 8 Oct 2012.

GALW15809 Collector: B. Queguineur

Bay of Brest, France. Subtidal at 4.8 m. Muddy bottom. 20 Jul 2010. GALW15746 Collectors: J. Grall and J. Hernandez

Kingstown Bay, Ireland. Subtidal. 10 Nov 2009. Collector: M. GALW15745 Moriarty

Kingstown Bay, Co. Galway, Ireland. Subtidal. 10 Nov 2009. Collector: M. Moriarty

North Quay, Lough Hyne, Ireland. Subtidal. 11 Feb 2004. Collector: GALW15811 J. Hall-Spencer

La Caleta, Cadiz, Spain. Subtidal, 1 m. - Apr 2009. Collector: R. GALW15770 Bermejo

Roscoff, France. Tidal pool. 22 Jul 2010. Collector: J. Hernandez GALW15733

Muckinish, Co. Galway, Ireland. Intertidal. 14 Sept 2012. Collectors: US170965 J. Hernández \& S. Heesch

Manra Fore Point, Cornwall, England. Intertidal. 01 Sept 2011. US170971 Collector: J. Hall-Spencer

Black Head, Co. Clare, Ireland. Intertidal. March 2010. Collector: J. US170957 Hernández

El Pardito-La lobera, Isla San Jose, BCS, Mexico. Subtidal, -10 m. 3 GALW15764 Dec 2008. Collector: J. Hernandez

Canal San Lorenzo, La Paz, BCS, Mexico. Subtidal, -15 m. 30 Mar GALW15767 2009. Collectors: J. Castillo and J. Hernandez

Bahía de Cadiz, Spain. May 2010. Collector: R. Bermejo

GALW15777

Mahahual, El Faro, Caribbean, Mexico. Subtidal, $-30 \mathrm{~cm} .13$ Jun 2009. Collectors: A. Sanchez and J. Hernandez

Xcalak, Caribbean, Mexico. Subtidal -30 cm. 11 Jun 2009.

GALW15778

GALW15779 Collectors: A. Sanchez and J. Hernandez

Bay of Brest, France. Subtidal, -6.2 m. Muddy bottom. 20 Jul 2010. GALW15750 Collectors: J. Grall and J. Hernandez

Kingstown Bay, Ireland. Subtidal. 10 Nov 2009. Collector: M. GAL15742 Moriarty

El Pardito-La Lobera, Isla San Jose, BCS, Mexico Subtidal at-10 m. GALW15734 03 Dec 2008. Collector: J. Hernandez

Canal San Lorenzo. La Paz, BCS, Mexico. Subtidal at-15 m. 30 Mar GALW15773 2009. Collectors: J. Castillo and J. Hernandez

Tenerife, Canary Islands, Spain. Unknown date. Collectors: Unknown

Kingstown Bay, Ireland. Subtidal. 10 Nov 2009. Collector: M. GALW15775 Moriarty

Isla Benencia, Galicia, Spain, type locality. Subtidal. 22 Apr 2010. GALW15776 Collectors: I. Barbara and V. Peña

Neotype Phymatolithon calcareum, Falmouth, England. 11 Dec $\quad$ BM 000712373 1983. Collector: W.F. Farnham

Muckinish, Ireland. Intertidal, on rock. 04 Nov 2009. Collector: J. GALW15780 Hernandez

Kingstown Bay, Ireland. Subtidal. 10 Nov 2009. Collector: M. GAL15781
JQ896277/JQ896250

JQ896278/JQ896251

JQ896279/JQ896252

JQ896263/JQ896236

JQ896264/JQ896237

Identical E35

Identical E35

Identical E35

JQ896265/JQ896238

JQ896266/JQ896239

Identical E27

Identical E27

JQ896282/JQ896255

JQ896283/JQ896256

Identical E153

Identical E153

Identical E153

JQ896262/JQ896235

JQ896280/JQ896253

JQ896284/JQ896257

JQ896267/JQ896240

JQ896281/JQ896254

JQ896261/JQ896234

JQ896260/JQ896233

JQ896268/JQ896241

JQ896270/JQ896243

JQ896273/JQ896246

JQ896271/JQ896244

JQ896272/JQ896245

JQ896258/JQ896231

JQ896275/JQ896248

JQ896276/JQ896249 Moriarty 
Table 1. Continued.

\begin{tabular}{llll}
\hline \hline $\begin{array}{l}\text { Family/species } \\
\text { (specimen code) }\end{array}$ & \multicolumn{1}{c}{ Collection information } & $\begin{array}{c}\text { GenBank accession } \\
\text { number * }\end{array}$ \\
\hline $\begin{array}{l}\text { P. purpureum (E28) } \\
\text { Kingstown Bay, Ireland. Subtidal. 10 Nov 2009. Collector: M. }\end{array}$ & GALW15782 & JQ896259/JQ896232 \\
$\begin{array}{l}\text { Phymatolithon laevigatum } \\
\text { (E76) }\end{array}$ & $\begin{array}{c}\text { Spiddal, Galway, Ireland. Intertidal, on rock. Apr 2010. Collector: M. } \\
\text { D. Guiry }\end{array}$ & JAW15783 & JQ896274/JQ896247 \\
$\begin{array}{l}\text { Unidentified Hapalidiaceae } \\
\text { (E58) }\end{array}$ & $\begin{array}{c}\text { Canal San Lorenzo, La Paz, BCS, Mexico. Subtidal, -15 m. 30 Mar } \\
\text { 2009. Collectors: J. Castillo and J. Hernandez }\end{array}$ & GALW15736 & JQ896269/JQ896242 \\
\hline \hline
\end{tabular}

All specimens are deposited in National University of Ireland, Galway Phycological Herbarium (GALW) and United States National Herbarium (US). The type material of Phymatolithon calcareum is housed at the Natural History Museum (BM), London. *SSU rDNA/psbA. Morphological features including reproductive status can be found in Supplementary material Table 3 and Supplementary material Figs 25-34.

(Lithophyllum hibernicum, Foslie, 1906); La Paz Bay and Canal de San Lorenzo, Gulf of California (Lithophyllum margaritae, Woelkerling \& Lamy, 1998).

Subtidal collections of rhodoliths were obtained by scuba diving and/or dredging. Intertidal collections were made by hand at low tide. Additional samples of encrusting coralline algae were collected from the same geographic areas using hammer and chisel to compare unattached and encrusting taxa within genera and species (mostly Lithophyllum and Phymatolithon) and to obtain taxa for which there were no available sequences in GenBank. These included Phymatolithon lamii (Lemoine) Chamberlain, P. lenormandii (Areschoug) Adey, Phymatolithon sp., Amphiroa rigida Lamouroux, Lithophyllum incrustans Philippi and $L$. byssoides (Lamarck) Foslie. Voucher specimens were deposited in the Phycological Herbarium, National University of Ireland, Galway (GALW) and United States National Herbarium (US).

Samples were air-dried, then cleaned and stored in labelled bags with silica gel. Identifications were based on descriptions and keys from Adey \& McKibbin (1970), Irvine \& Chamberlain (1994), Littler \& Littler (2000), Bressan \& Babbini (2003), Yabur-Pacheco \& Riosmena-Rodríguez (2006) and Riosmena-Rodríguez et al. (2012), and if possible by comparison with type material or specimens from the type locality that resembled type descriptions.

If identification required detailed anatomical examination, this was undertaken using light microscopy and SEM. For light microscopy, a fragment of the specimen was decalcified using a solution of $10 \%$ acetic acid overnight. Then the fragment was hand-sectioned, stained with $1 \%$ aniline blue and softened with $1 \%$ hydrochloric acid; sections were mounted on a non-permanent slide. For SEM, additional fragments were removed from the specimen using a razor blade under a stereomicroscope. The fragments were positioned on a stub to show surface view, transverse view and reproductive structures, and gold-coated. Anatomical observations were made using a Hitachi S-4700 Scanning Electron Microscope in the National Centre for Biomedical Engineering Science (NCBE) at NUI, Galway. Specimens identified as Lithophyllum species were analysed to record life-history phases, including sporophyte (bi-tetrasporangial conceptacles), gametophyte (female or male conceptacles) or fertile carposporophytes following details in Irvine \& Chamberlain (1994). Many specimens were unfertile, so the phase was recorded as unknown.

In order to identify rhodoliths as accurately as possible, type material, topotype material and other historical collections of the following species were examined and DNA was extracted: Phymatolithon calcareum (neotype, BM000712373, Natural History Museum, London [BM] Box 1626), Lithothamnion corallioides (neotype, BM000530511), Lithophyllum hibernicum Foslie (historical collection from Ireland, BM000044818, BM Box 578) and Lithophyllum duckerae Woelkerling (historical collection from England, BM000044838, BM Box 598). In the case of Mesophyllum sphaericum, sequences from our collection were compared with the molecular data published from the holotype (Peña et al., 2011; Pardo et al., 2014). Topotype specimens were examined in detail and the correspondence of their morphologies with the original descriptions was verified, in order to avoid possible misidentifications with similar species occurring in the same localities.

\section{DNA extractions, PCR amplification and sequencing}

DNA was extracted from 200 specimens of rhodoliths $(\mathrm{n}=$ $178)$, crusts $(n=19)$ and geniculate taxa $(n=3)$ as part of this project and ongoing taxonomic analysis (Hernandez-Kantun, 2013). Extraction of DNA from type material was performed separately, isolated from other extractions, to prevent risk of contamination. DNA extractions were performed using fragments of thalli that appeared visually clean and free of epiphytes. A fragment of approximately $5 \mathrm{~mm}$ diameter was excised from the specimen. DNA was extracted using the Qiagen DNeasy Blood and Tissue Kit ${ }^{\circledR}$ (Qiagen, Crawley, UK) following the modified protocol of Broom et al. (2008). All samples extracted were coded using a label of the form EXXX (e.g. E160). PCR for the psbA gene was performed using the primers $p s b \mathrm{~A}-\mathrm{F} 1$ and $p s b \mathrm{~A}-\mathrm{R} 2$ based on the protocols of Yoon et al. (2002). The protocols used to amplify the SSU rDNA gene employed G01 as forward primer and G14 as reverse primer for the first fragment, and G04 as forward primer and G07 as reverse primer for the second fragment, following Saunders \& Kraft (1994). The mix used for both markers consisted of $5 \mu$ l of buffer ( $1 \times$ units), $2 \mu \mathrm{lNTPs}(10$ $\mathrm{mM}), 1.5 \mu \mathrm{MgCl}_{2}(1.5 \mathrm{mM}), 1 \mu \mathrm{l}$ of each primer (forward and reverse) $(10 \mathrm{pM}), 0.3 \mu \mathrm{l}$ Invitrogen Taq polymerase (Invitrogen, Carlsbad, California) $(1.5 \times), 38.2 \mu$ HyPure $^{\mathrm{TM}}$ Cell Culture Grade Water (Thermo Scientific, USA) and $1 \mu \mathrm{l}$ DNA template (in some cases a dilution of 1/10 from the extracted sample was used). Positive and negative controls were included in all PCR runs of recently collected samples. Special attention was devoted to DNA extractions of type material to corroborate the absence of possible contamination; each reaction was performed separately without a 
positive control. The amount of DNA in the PCR products was quantified visually in agarose gels stained with SYBR Safe ${ }^{\circledR}$ DNA (Invitrogen) against a standard (HyperLadder II, Bioline, London, UK) under UV light. The products of successful reactions were purified using the Qiagen MinElute Gel Extraction Kit (Qiagen). PCR products of expected length, yield and purity were sequenced commercially (Macrogen, Seoul, South Korea, or GATC Biotech, Konstanz, Germany) using the same primer pairs as for the PCR reaction.

\section{Phylogenetic analyses}

The genera represented in the dataset obtained from newly sequenced samples of rhodoliths and crustose corallines included Lithophyllum and Neogoniolithon (Corallinaceae) and Lithothamnion, Phymatolithon and Mesophyllum (Hapalidiaceae). Additional sequences were acquired from GenBank to represent missing/uncovered lineages in both orders Corallinales and Sporolithales. All sequences published in previous phylogenies by Broom et al. (2008), Bittner et al. (2011) and Kato et al. (2011) were included with the only restriction being that $p s b \mathrm{~A}$ and SSU sequences were obtained from the same specimen (Supplementary Table 1). Geniculate and non-geniculate genera represented were the Corallinaceae Titanoderma, Amphiroa, Arthrocardia, Cheilosporum, Corallina, Jania, Hydrolithon, Lithophyllum, Mastophora, Metagoniolithon, Neogoniolithon, Pneophyllum, Spongites and the Hapalidiaceae Lithothamnion, Mesophyllum, Phymatolithon and Synarthrophyton. An initial analysis of $p s b \mathrm{~A}$ and SSU sequences from GenBank and those obtained in the present study was performed using Neighbour-joining (NJ) in Mega version 5 (Tamura et al., 2011) with default settings; this distance method was used to discriminate and eliminate identical sequences and those yielding extraordinarily long branches (presumed errors, only found in sequences from GenBank). After this analysis 59 sequences from GenBank were retained. Morphological information for voucher specimens with respect to the unattached habit was obtained by contacting the corresponding authors of the previous studies or from the herbaria where the vouchers are preserved (PC, RYU, WELT; abbreviations follow Index Herbariorum (Thiers, 2014).

Many Atlantic European sporophyte specimens of the Lithophyllum incrustans/L. dentatum/L. fasciculatum complex were sequenced, representing both crusts and rhodoliths. This dataset was used to investigate the relationship of crusts and rhodoliths within species.

Phylogenetic analyses were performed on four datasets: (1) SSU sequence data, (2) psbA sequence data, (3) a concatenated dataset of SSU and $p s b$ A sequences and (4) a $p s b \mathrm{~A}$ dataset for sequences of the Lithophyllum incrustans/L. dentatum/L. fasciculatum complex. All four datasets were aligned using ClustalW in Mega version 5 (Tamura et al., 2011) with default settings. In all datasets with SSU, highly variable sections (with large indels which made unambiguous alignment impossible) were removed, as in previous studies (Bittner et al., 2011; Kato et al., 2011).

Publicly available GenBank sequences from members of the order Sporolithales were used as outgroups in the $p s b \mathrm{~A}$, SSU and psbA+SSU datasets: Sporolithon sp. (SSU gene GQ917379/psbA gene GQ917500), 'rhodolith non- geniculate' (EF628212/DQ167875) and Heydrichia homalopasta (EF628210/DQ167931). Members of the Sporolithales have been used previously as outgroup taxa for analyses of the Corallinales based on the close phylogenetic relationship of these orders (Bittner et al., 2011; Kato et al., 2011). Lithophyllum byssoides was used as outgroup taxon for the $p s b$ A dataset of the Lithophyllum incrustans/L. dentatum $/ L$. fasciculatum complex. In terms of partitioning strategy, partition by codon (first, second and third position) was applied to the $p s b \mathrm{~A}$ dataset, no partition was used for the SSU dataset and partition by codon plus the whole SSU gene (therefore, four partitions) was applied to the concatenated dataset, following recommendations by Verbruggen et al. (2010).

Phylogenetic reconstruction for the $p s b \mathrm{~A}, \mathrm{SSU}$ and $p s b \mathrm{~A}$ + SSU datasets was performed using Maximum likelihood (ML) in RAxML 1.3 (Mac version, Silvestro \& Michalak, 2011) and Bayesian inference (BI) in MrBayes v. 3.2.2 (Huelsenbeck \& Ronquist, 2001). RAxML by default works with just one substitution model, GTR (General Time Reversible). The GTR model was selected with invariant sites and gamma distribution for each of the partitions. The parameters applied to the Bayesian analyses were chosen using jModelTest 0.1.1 (Posada, 2008) with the Bayesian Information Criterion with partitions previous explained. Models selected were GTR $+\mathrm{G}+\mathrm{I}$ for the three codon positions and the SSU gene. BI was performed with MrBayes v. 3.2.2 running four Monte Carlo Markov chains for a total of 12 million generations for the concatenated dataset and 5 million generations for the single marker; tree sampling was carried out every thousand generations and the stationary distribution of the runs was verified with Tracer v.1.5 (Rambaut \& Drummond, 2007) before stopping the program; 3000 trees were discarded as burn-in for the concatenated dataset and 1250 trees for the single marker analysis, using the remaining trees to build the $50 \%$ majority-rule consensus trees.

Treefinder (PC Version April 2008; Jobb, 2008) was additionally used for the ML analysis of the concatenated dataset, because Treefinder has the option of selecting separate evolutionary models for each of the partitions. Model selection for the concatenated dataset in Treefinder resulted in $\mathrm{TN}+\mathrm{G}$ (first codon position of $p s b \mathrm{~A}$ ), HKY (second codon position of $p s b \mathrm{~A}), \mathrm{HKY}+\mathrm{G}$ (third codon position of $p s b \mathrm{~A}$ ) and $\mathrm{TN}+$ $\mathrm{G}$ (SSU gene). Non-parametric bootstrap (BP) analyses were performed with the same software using 500 resamplings for ML in Treefinder (tML) and 1000 resamplings in RAxML. Distance analyses were performed on the $p s b \mathrm{~A}$ dataset for Lithophyllum incrustans/L. dentatum/L. fasciculatum using Neighbour-joining (NJ) with 1000 BP resampling in Mega version 5 (Tamura et al., 2011) and RAxML with settings as for previous datasets.

\section{Results}

This study provided 87 new high-quality sequences (i.e. sequences with chromatograms entirely or mostly consisting of clear unique peaks) for new collections and type specimens. Among these sequences, there were 27 distinct genotypes for SSU and 27 complementary $p s b$ A sequences referable to the same specimens. These sequences represented 25 taxa in the reconstructions and the 27 newly obtained sequences 
for each marker constitute $31.4 \%$ of the 86 total sequences used (including GenBank sequences). The single marker alignment was 858 bp for $p s b \mathrm{~A}$ and 1532 bp for SSU. The concatenated alignment consisted of the same 86 sequences as in the single marker alignment of $2390 \mathrm{bp}$.

Phylogenetic reconstruction using SSU sequences of rhodolith-forming species obtained moderate to high support for several internal nodes (Fig. 1) and for $p s b \mathrm{~A}$ there was high support for terminal nodes but low support for internal nodes (Fig. 2). The concatenated phylogeny (Fig. 3) resulted in better supported internal and terminal nodes. The concatenated analyses (Fig. 3) resolved family Corallinaceae as monophyletic with robust support $(98 \% / 99 \% / 1.00$ respectively, in Treefinder ML, RAxML and BI) and monophyly of the Hapalidiaceae was fairly well supported $(70 \% / 88 \% / 0.89)$.

In the family Corallinaceae, the subfamily Lithophylloideae, consisting of the genera Lithophyllum (including 'Titanoderma') and Amphiroa, received full bootstrap support. The genus Lithophyllum as currently circumscribed was not monophyletic, with several well-supported Lithophyllum clades within the Lithophylloideae (Fig. 3). The only well-supported lineage ( $>80 \% \mathrm{BP}$ ) for which there were discrepancies between the two genes was a clade formed by sequences of Neogoniolithon in which the positions of Neogoniolithon sp. GQ917434/GQ917489, Neogoniolithon sp. GQ917402/GQ917331 and Neogoniolithon brassica-florida B576018/AB576032 differed between the trees.

In the Hapalidiaceae, there were few well-resolved clades, and those in which Lithothamnion and Mesophyllum occurred were unsupported in the single-marker phylogenies and concatenation did not result in a substantial increase in support (Figs 1-3). All branches recovered with high support in the single-marker analyses were equally well supported in the concatenated analyses (Fig. 3).

Overall, 18 taxa of rhodolith-forming corallines were represented for the first time in the phylogenetic reconstruction of the Corallinales (Table 1, Fig. 3). Rhodolithforming taxa shown in Figs 4-22 include members of the genera Hydrolithon, Lithophyllum, Lithothamnion, Mesophyllum, Neogoniolithon and Phymatolithon. In some specimens the alga grew around a core formed by a pebble or a stone fragment, whereas in others it formed a free, branched mass (absence/presence of a core is marked in Figs 4-22). Among type material (Table 2), SSU and psbA sequences were obtained from the neotype of Phymatolithon calcareum (BM000712373), while samples of historical material of Lithophyllum hibernicum, L. duckerae and the holotype of Lithothamnion corallioides failed to provide sequences (Table 2). By contrast, material from the type locality of $L$. corallioides was successfully sequenced. Lithophyllum margaritae presented additional difficulties, since two genotypes were found with the morphology ascribed to the species.

Six taxa in the genus Lithophyllum exhibited the ability to form rhodoliths: Lithophyllum sp. 1 (E27, E35, E132, E137, Ireland and Atlantic and Mediterranean France), Lithophyllum sp. 2 (E149, Atlantic Spain), Lithophyllum sp. 3 (E153, Atlantic France), L. margaritae (E57, Gulf of California), L. margaritae (E68, Gulf of California) and L. cf. bamleri (GQ917417/GQ917473, Fiji) (Fig. 3). They were scattered in the Lithophylloideae clade and did not form a monophyletic group (Fig. 3). Within the Lithophylloideae, the only well-supported clade of samples forming rhodoliths was that containing the morpho-species complex $L$. incrustans $/ L$. dentatum $/ L$. fasciculatum, here called Lithophyllum sp. 1, Lithophyllum sp. 2 and Lithophyllum sp. 3. This clade also included an encrusting $L$. incrustans sample from Brittany (GQ917385/GQ917440; Bittner et al., 2011, Fig. 3). Rhodolith samples attributed to the morphospecies $L$. margaritae consisted of two cryptic species that were recovered in different clades (Fig. 3). Based on these results, within the genus Lithophyllum the rhodolith habit is not a synapomorphy.

Specimens of Neogoniolithon formed a well-supported clade (Fig. 3). Within this clade, rhodolith-forming taxa were clustered in a well-supported monophyletic sub-clade. The samples forming rhodoliths were Neogoniolithon strictum (Foslie) Setchell \& Mason (E100) and N. spectabile (Foslie) Setchell \& Mason (E93), both from Caribbean Mexico, $N$. brassica-florida (E151) from Spain, which was not closely related to samples from Japan attributed to this species in GenBank (Fig. 3), and an unidentified Neogoniolithon sp. from New Caledonia (GQ917434/ GQ917489, Bittner et al., 2011). Based on these results, the rhodolith habit is a synapomorphy within the genus Neogoniolithon.

Information relating to the habit of specimens sequenced in previous studies indicated that a specimen of Hydrolithon (H. reinboldii GQ917376/GQ917485, Bittner et al., 2011) from New Caledonia is a rhodolith. Our results showed that this specimen is closely related to encrusting forms (Fig. 3).

In the family Hapalidiaceae, analyses included several taxa of Lithothamnion forming rhodoliths: $L$. glaciale and $L$. corallioides from Atlantic Europe (material from the type locality in the Bay of Brest, France) and L. muelleri from the Gulf of California (Fig. 3). They were weakly grouped with an encrusting Lithothamnion sp. from Fiji (GQ917405/ GQ917461) but there was not enough resolution in this part of the tree. Mesophyllum species were paraphyletic and belonged to a lineage also containing Synarthrophyton and Lithothamnion taxa without a clear generic limit even taking into account the generitype species $M$. lichenoides (sequences not corroborated with type material, Fig. 3). Rhodolith taxa in the 


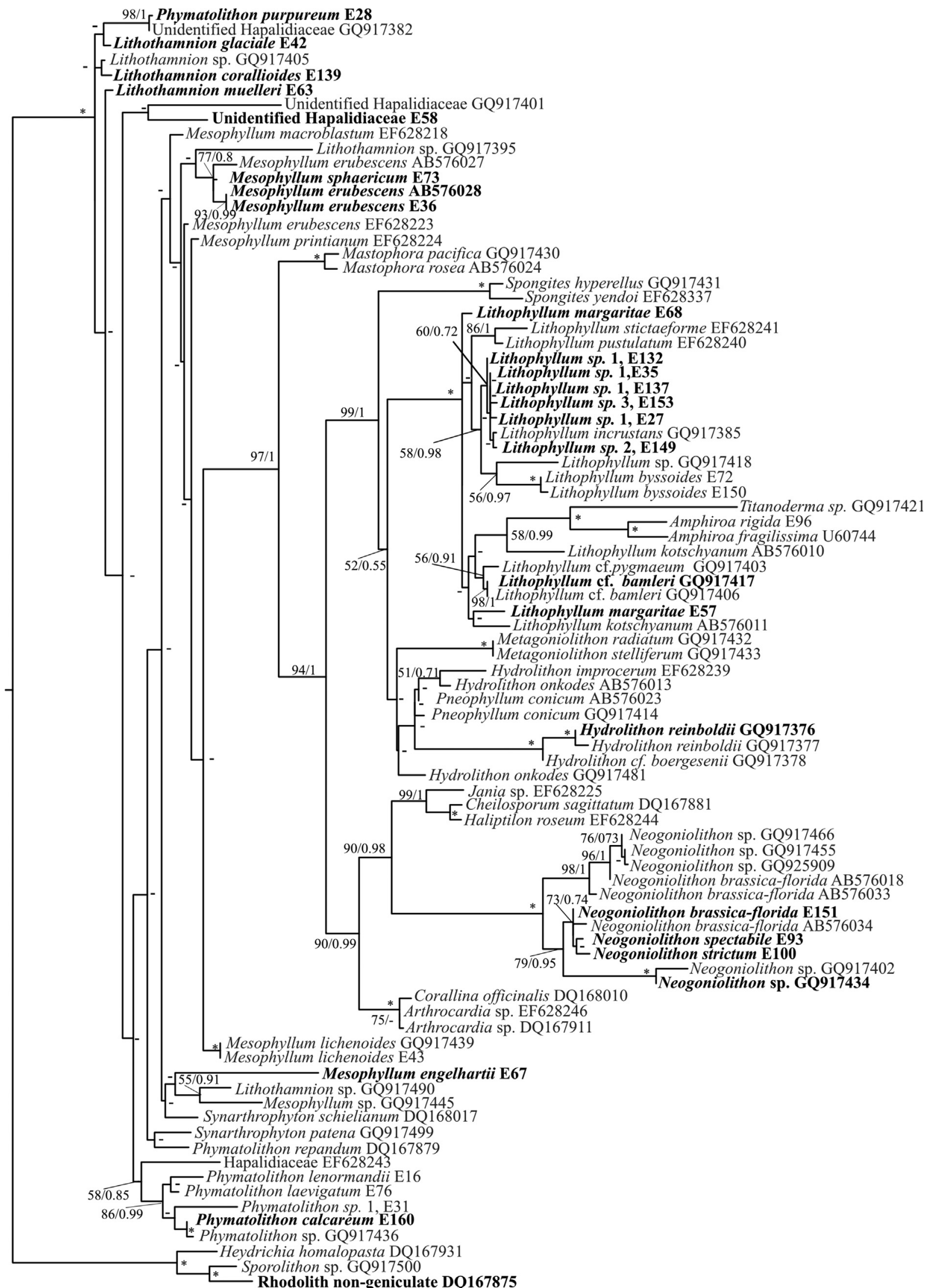

$0.05 \overline{\text { substitutions/site }}$

Fig. 1. Phylogenetic tree inferred from RAxML analysis of SSU rDNA sequences for the order Corallinales including samples (bold face type). Sequences from GenBank are indicated using accession numbers, and sequences produced in the present study are indicated with the EXXX code (e.g. E160 for Phymatolithon calcareum). Support values are shown at the node as RAxML bootstrap values $>50 \%$ and complementary posterior probabilities from BI. Nodes marked with * have $100 \% / 1.00$ support and those with - are not supported (less than $50 \%$ support and less than $0.7 \mathrm{BI}$ posterior probability). 


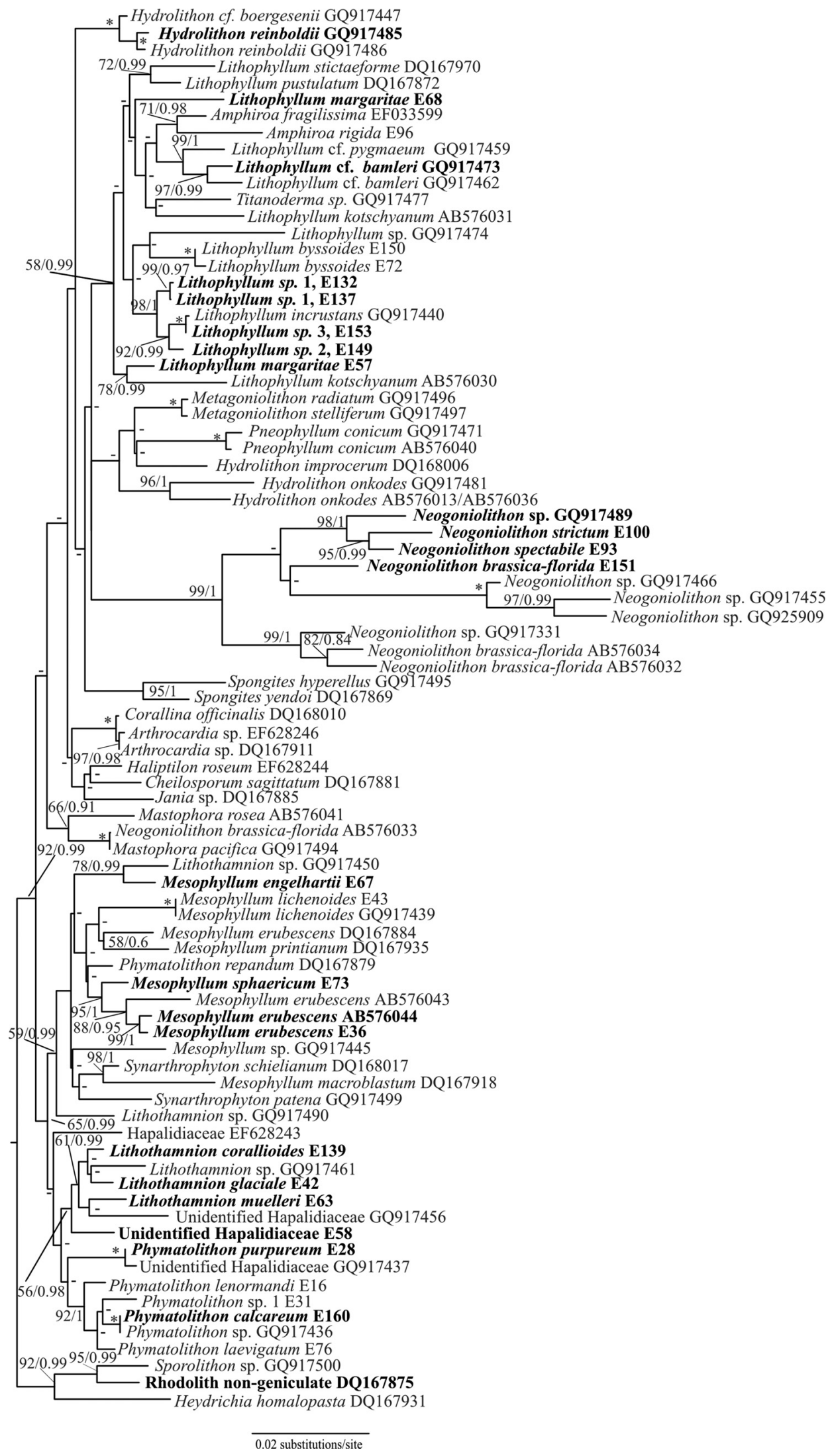

Fig. 2. Phylogenetic tree inferred from RAxML analysis of $p s b \mathrm{~A}$ for the order Corallinales including rhodolith-forming species. Sequences from GenBank are indicated using accession numbers and new sequences produced in the present study are indicated with the EXXX code. Samples with rhodolith morphology are marked in bold. Support values are shown at the node as RAxML bootstrap values $>50 \%$ and BI posterior probabilities from. Nodes marked with * have $100 \% / 1$ support and nodes with - are not supported $(<50 \%$ support and $<0.7$ posterior probability). 


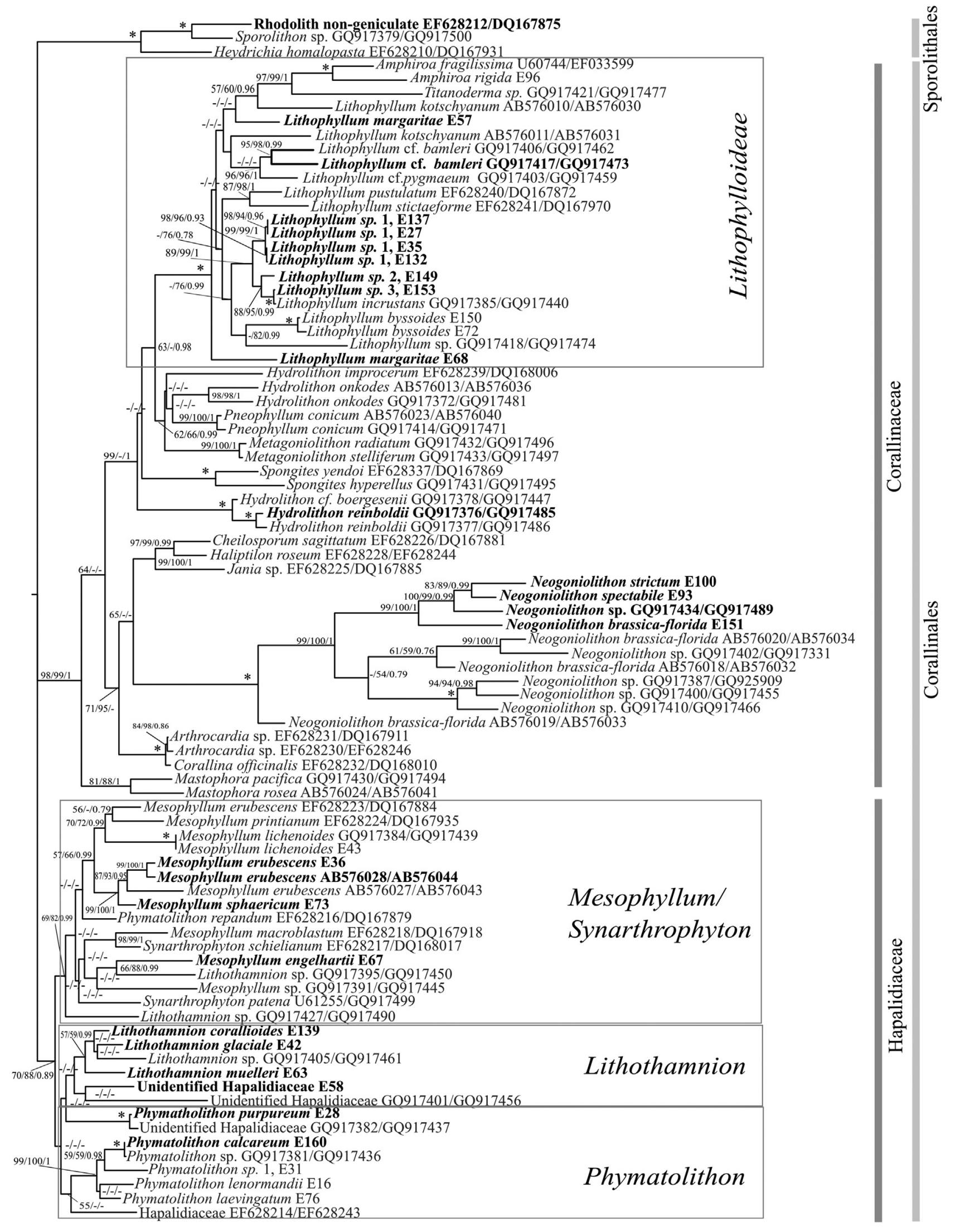



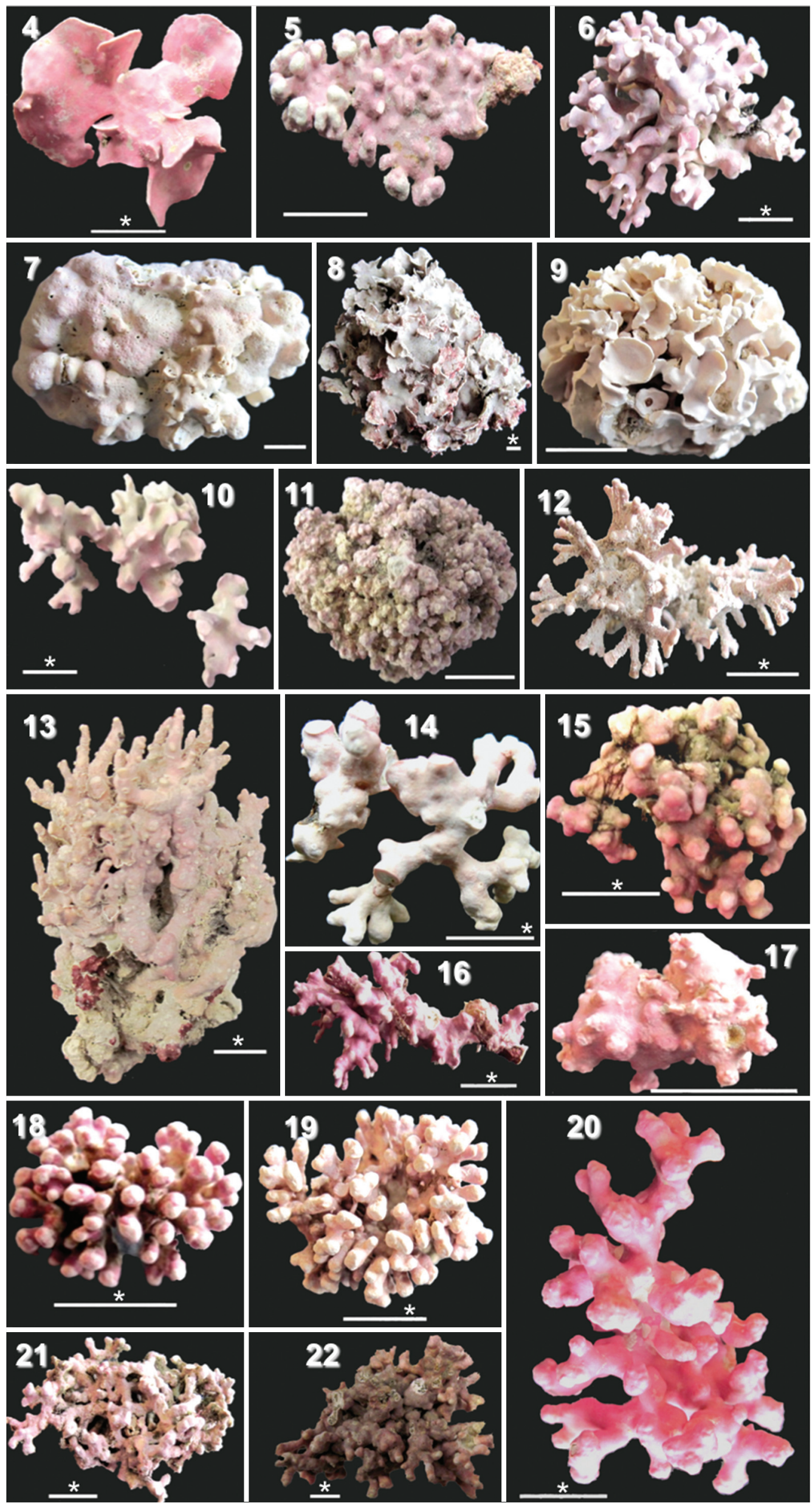

Figs 4-22. Rhodolith-forming taxa studied. Fig. 4. Lithophyllum margaritae E57. Fig. 5. L. margaritae E68. Fig. 6. Lithophyllum sp. 1 E27 (specimen with thick branches). Fig. 7. Lithophyllum sp. 3. E153 (compact ball with some protuberances). Fig. 8. Lithophyllum 
Table 2. An annotated list of important historical and topotype specimens that were examined in the study.

\begin{tabular}{|c|c|c|c|c|}
\hline Species & Herbarium material & SSU & $p s b \mathrm{~A}$ & Comments \\
\hline $\begin{array}{l}\text { Lithophyllum } \\
\text { hibernicum }\end{array}$ & Specimen BM44818 & $\begin{array}{l}\text { Amplification } \\
\text { failed }\end{array}$ & $\begin{array}{l}\text { Amplification } \\
\text { failed }\end{array}$ & $\begin{array}{l}\text { Possibly the same collection as the holotype (unpublished } \\
\text { data) mentioned by Irvine \& Chamberlain (1994) }\end{array}$ \\
\hline $\begin{array}{l}\text { Lithophyllum } \\
\text { duckerae }\end{array}$ & Herbarium material BM44838 & $\begin{array}{l}\text { Amplification } \\
\text { failed }\end{array}$ & $\begin{array}{l}\text { Amplification } \\
\text { failed }\end{array}$ & $\begin{array}{l}\text { The specimen is cited and shown by Irvine \& Chamberlain } \\
\text { (1994) }\end{array}$ \\
\hline $\begin{array}{r}\text { Lithothamnion } \\
\text { corallioides }\end{array}$ & $\begin{array}{l}\text { Holotype, BM530511, Crouan \& } \\
\quad \text { Crouan, } 1867\end{array}$ & $\begin{array}{l}\text { Amplification } \\
\text { failed }\end{array}$ & $\begin{array}{l}\text { Amplification } \\
\text { failed }\end{array}$ & $\begin{array}{l}\text { Specimen glued to the herbarium sheet. Glue may have } \\
\text { denatured DNA }\end{array}$ \\
\hline $\begin{array}{r}\text { Lithothamnion } \\
\text { corallioides }\end{array}$ & $\begin{array}{l}\text { Sample E139 from type locality } \\
\text { (Topotype). }\end{array}$ & JQ896261 & JQ896234 & $\begin{array}{l}\text { Specimens obtained in } 2010 \text { from the type locality Rade de } \\
\text { Brest, France (Crouan \& Crouan, 1867); anatomical } \\
\text { features agreed with description (Irvine \& Chamberlain, } \\
\text { 1994) }\end{array}$ \\
\hline $\begin{array}{l}\text { Phymatolithon } \\
\text { calcareum }\end{array}$ & Sample E160, Neotype & JQ896258 & JQ896231 & $\begin{array}{l}\text { Complete anatomical description in Woelkerling \& Irvine } \\
\text { (1986) }\end{array}$ \\
\hline $\begin{array}{l}\text { Mesophyllum } \\
\text { sphaericum }\end{array}$ & $\begin{array}{l}\text { Sample E73 from type locality } \\
\text { (Topotype) and identical to the } \\
\text { Holotype }\end{array}$ & JQ896272 & JQ896245 & Type locality, Ría de Arousa, Spain (Peña et al., 2011) \\
\hline $\begin{array}{l}\text { Lithophyllum } \\
\text { margaritae }\end{array}$ & $\begin{array}{l}\text { Samples } \mathbf{E 5 7} \text { and } \mathbf{E 6 8} \text { from the } \\
\text { type locality }\end{array}$ & $\begin{array}{l}\text { JQ896280 and } \\
\text { JQ89626, } \\
\text { respectively }\end{array}$ & $\begin{array}{l}\text { JQ896253 and } \\
\text { JQ896235, } \\
\text { respectively }\end{array}$ & $\begin{array}{l}\text { Type locality, La Paz, BCS, Mexico (Riosmena-Rodríguez } \\
\text { et al., 1999). Mixed results from the specimens cannot } \\
\text { corroborate the identity of the specimens }\end{array}$ \\
\hline
\end{tabular}

Failed sequencing for each marker is detailed for each specimen.

genus Mesophyllum were closely related to encrusting taxa, so the ability to form unattached structures is widely distributed in this clade. On the other hand, the rhodolith samples Mesophyllum erubescens (Foslie) Me. Lemoine (E36 and AB576028) and M. sphaericum were members of the same well-resolved clade, whereas M. engelhartii (Foslie) Adey (crustose, E67) was not closely related to them. Mesophyllum erubescens was polyphyletic and specimens referred to this species were related to other Mesophyllum taxa in different clades (Fig. 3).

Most of the members of the genus Phymatolithon, including the generitype $P$. calcareum (neotype) and other European taxa, Phymatolithon sp. 1 (E31), P. lenormandi (E16) and P. laevigatum (E76), were recovered in a well-resolved clade consisting of both crustose and rhodolith forms (Fig. 3). However, the rhodolith P. purpureum (E28) was not closely related to this clade (Fig. 3). Based on these results the rhodolith habit is not identifiable as a synapomorphy within this genus.

Analyses of life-history phases showed that tetrasporophytes of Phymatolithon calcareum were only recorded as rhodoliths in the present study (sample E160, and identical sequences from other specimens); this species was not detected amongst crustose samples. Similarly, P. purpureum tetrasporophytes were only recorded as branched thalli without a core, that formed rhodolith beds (sample E28 and identical sequences from other specimens), and no encrusting forms were found from intertidal rocky shores. Additionally, an unidentified sequence from Brittany (GQ917382/GQ917437) of unknown phase and habit was probably conspecific with $P$. purpureum (Fig. 3).

Further analysis of life-history phases of members of the genus Lithophyllum (Figs 23, 24) showed that sporophytes of Lithophyllum sp. 3 exhibited both habits in the intertidal, consisting of both encrusting forms (E211, E322 and two GenBank samples, one identified as L. incrustans) and rhodoliths (E153, E324). Both rhodolith specimens had a core; they were found in a tidal channel surrounded by other rhodoliths but not forming a bed. On the other hand, Lithophyllum sp. 1 specimens were all subtidal rhodoliths. Anatomical examination showed that the fertile sporophytes (E132, E276, E309) were rhodoliths with a core of a small stone/shell whereas the nonfertile rhodoliths (E25, E27, E35, E69, E137, E231) were homogeneous, highly branched and lacked a core (Supplementary Table 2). All Lithophyllum sp. 1 specimens obtained in the present study were bedforming (GQ917706 from Brittany was of unknown habit and phase).

Figs 4-22. Continued

sp. 1. E35 (specimen with thin lamellate branches). Fig. 9. Lithophyllum sp. 2. E149 (specimen with thin lamellate branches). Fig. 10. Lithophyllum sp. 1 E137 (specimen with thick branches). Fig. 11. Neogoniolithon brassica-florida E151. Fig. 12. N. spectabile E93. Fig. 13. N. strictum E100. Fig. 14. Lithothamnion muelleri E63. Fig. 15. L. corallioides E139. Fig. 16. L. glaciale E42. Fig. 17. Mesophyllum engelhartii E67. Fig. 18. M. sphaericum E73. Fig. 19. M. erubescens E36. Fig. 20. Unidentified Hapalidiaceae E58. Fig. 21. Phymatolithon purpureum E28. Fig. 22. P. calcareum E160. * on the scale bar denotes lack of a stone core. Scale bars $=1 \mathrm{~cm}$. For collection details see Table 1. 

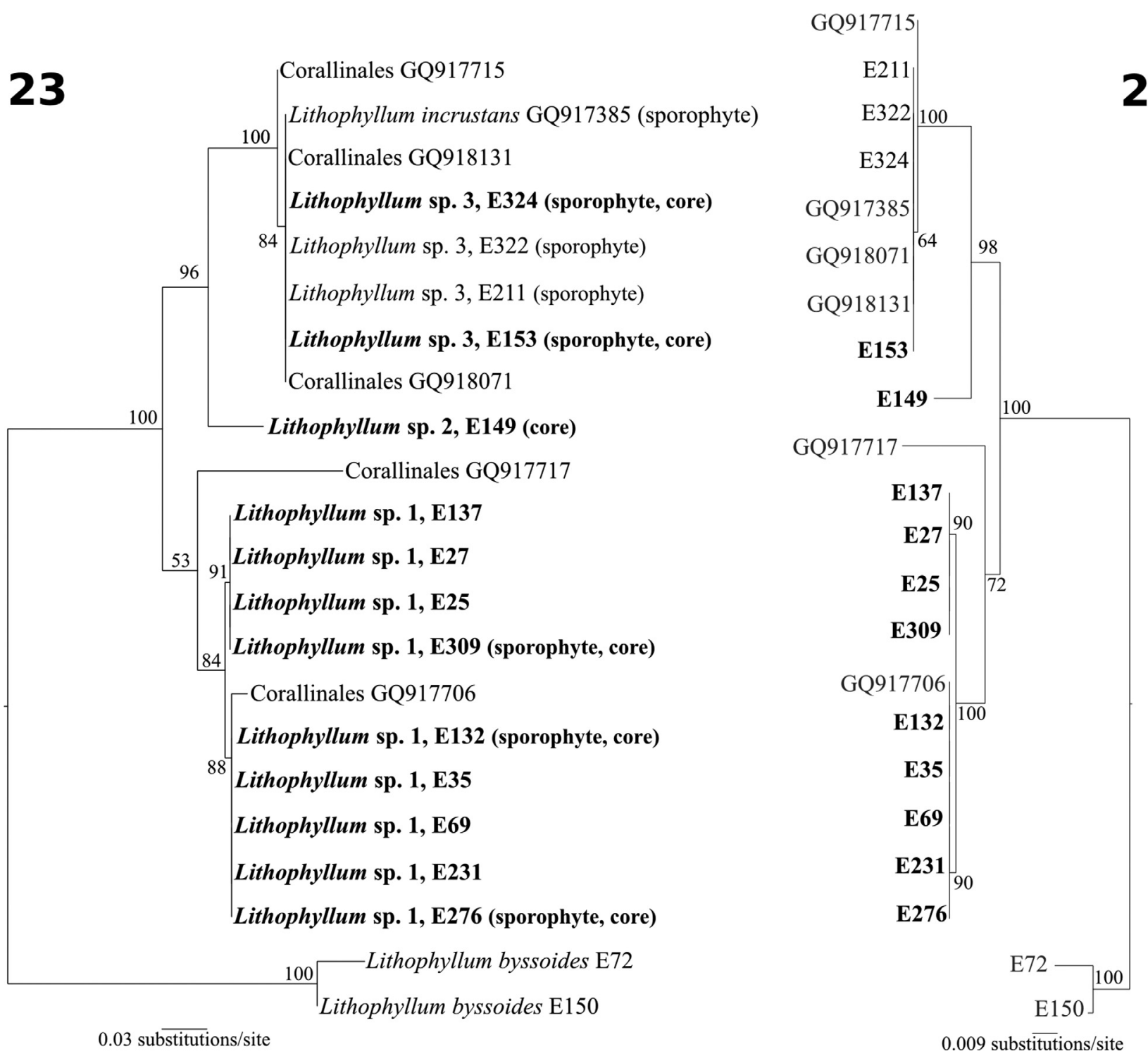

Figs 23-24. Phylogenetic reconstruction for rhodolith-forming species in the genus Lithophyllum around Europe using psbA sequences. Fig. 23. Tree inferred from ML analysis. Fig. 24. Tree inferred from NJ analysis. Sequences from GenBank are indicated using $p s b \mathrm{~A}$ accession numbers and new sequences produced in the present study are indicated with the EXXX code. Taxa forming rhodoliths are marked in bold and when known life-history phase and core are marked. Bootstrap values are shown near each branch.

\section{Discussion}

The present study is the first to analyse comprehensively the rhodolith-forming feature from an evolutionary perspective and includes a phylogenetic analysis of all genera of Corallinales that have been reported to form rhodoliths (Harvey \& Woelkerling, 2007), i.e. Lithophyllum, Neogoniolithon, Phymatolithon, Lithothamnion, Mesophyllum, Hydrolithon and Spongites. Based on our results, the characteristic of forming a rhodolith can be interpreted either as a feature arising by chance in different lineages (convergence) or as a feature conferring advantages in terms of survival that becomes fixed in a lineage (synapomorphy). In the first scenario, a single species has the potential to form both rhodoliths (with a core) and crusts, resulting from a combination of genotypic and environmental drivers (such as in
Lithophyllum sp. 3). In contrast, in rhodolith-forming clades (Neogoniolithon spectabile $+N$. strictum) and species (e.g. Lithophyllum sp. 1, Phymatolithon calcareum) in which this feature appears to be a synapomorphy, the rhodoliths rarely have a core and rarely encrust bedrock. Both sporophytes and/or gametophytes are associated with rhodolith beds in the case of Lithophyllum sp. 1, and Phymatolithon calcareum, suggesting a complete adaptation to the unattached habit. Sporophytes of Lithophyllum sp. 1 were found only as rhodoliths in maerl beds while Phymatolithon calcareum consisted of gametangial specimens forming thin crusts growing on gravel, dead maerl and pebbles associated with maerl beds composed of sporophytes (Mendoza \& Cabioch 1998; Peña et al., 2014b).

The rhodolith habit was not resolved as a synapomorphy within most of the genera in the Corallinales, 
the only exception being a clade within the genus Neogoniolithon (Fig. 3, N. spectabile, N. strictum and $N$. brassica-florida). Two species, N. spectabile and $N$. strictum, occur in seagrass beds and coral reefs in the tropics (Littler \& Littler, 2000), which could suggest a complete adaptation to environments where rocky shores are uncommon compared with seagrass beds; nevertheless, information is lacking for $N$. brassica-florida, which was reported by Milazzo et al. (2014) in Italy as a crust in the intertidal. More information is necessary to confirm conspecificity among crusts and rhodoliths identified as this species.

The finding that the rhodolith habit is in some cases occasional and in other cases constant in different lineages of Lithophyllum (Figs 3, 23-24) suggests that the taxonomic value of this feature is not general and needs to be considered separately for different species. This has implications for the taxonomy of rhodolith-forming species, since the main characteristic for the identification of at least four Atlantic European Lithophyllum taxa [L. hibernicum, L. fasciculatum (Lamarck) Foslie, L. duckerae and L. dentatum (Kutzing) Foslie] reported from the British Isles and Brittany is the rhodolith habit (Irvine \& Chamberlain, 1994). Historical records will require re-analysis after this finding and as part of any taxonomic study of the genus in Europe.

The inclusion for the first time of numerous sequences from rhodolith-forming species in the phylogeny of coralline algae yielded changes in strength of clades rather than in the general topology of phylogenies compared with previous studies. For example in Phymatolithon, the inclusion of additional taxa and type material produced a better-supported clade. The phylogenetic reconstruction of the order Corallinales in our concatenated dataset (SSU and psbA, Fig. 3) agreed with Broom et al. (2008) and Kato et al. (2011), who used the same combination of markers. The phylogeny of Bittner et al. (2011) was based on four markers (LSU, SSU, psbA and cox 1 ) and, although it differs from the present study in some deep branches (Fig. 3), it is generally in agreement with ours. For example, clade $\mathrm{L}$ in Bittner et al. (2011) corresponds to the subfamily Lithophylloideae in the present study, and these authors also found no clear separation of Lithophyllum from the rest of the genera in the subfamily (in particular from the heterotypic synonym 'Titanoderma').

\section{Cryptic species and taxonomic problems}

Determining specific names for some Lithophyllum specimens proved to be difficult and unambiguous identification at species level was not possible for some lineages (Figs 1-3, 23-24). For example, Lithophyllum sp. 1 displayed features ascribed to
L. fasciculatum and L. dentatum (lamellate branches, teeth on the margins of the lamellae and thickness of branches) and no clear differentiation between these two species could be established. These morphological characters were used by Foslie (1900), Irvine \& Chamberlain (1994) and Cabioch (1969) to separate L. fasciculatum from similar species. Irvine \& Chamberlain (1994) pointed out that at the microscopic scale, L. fasciculatum may show up to three layers of epithallial cells while $L$. dentatum had only a single layer. However, the type material of Millepora fasciculata Lamarck, the basionym of L. fasciculatum, probably collected in the Mediterranean, does not belong to the genus Lithophyllum and instead is a member of the genus Lithothamnion (Woelkerling \& Lamy, 1998; Basso et al., 2004). Therefore the name L. fasciculatum, traditionally used in Ireland and Brittany for globular to subglobular rhodoliths with flattened to cylindrical branches (Peña et al., 2013), is not available for these specimens, which should be subject to nomenclatural revision. Lithophyllum sp. 2, which is not conspecific with Lithophyllum sp. 1 (Figs 3, 23-34) also shows typical features of $L$. dentatum (marginal teeth on the branches), making it difficult to assign the name $L$. dentatum to any of the clades with certainty. Finally, Lithophyllum sp. 3 was conspecific with a sequence in GenBank reported as L. incrustans (GQ917385/GQ917440) but morphological features such as colour and the presence of a prominent columella were not enough to identify this species since many specimens in Lithophyllum sp. 2 presented similar features. Therefore, despite employing all morphological and anatomical features available to identify these three taxa (Lithophyllum species 1, 2 and 3), it is currently impossible to unambiguously assign a name to any of the entities. We provisionally attribute these specimens to a Lithophyllum incrustans/L. dentatum complex (including Lithophyllum spp. 1-3 in the reconstructions) and avoid the name $L$. fasciculatum for the reasons explained.

In our phylogenetic reconstructions, in contrast to previous phylogenies, type material or topotype material was included that helped to identify samples of some lineages. In particular sequences from the generitype of Phymatolithon (P. calcareum E160) were acquired for the first time, so the strongly supported clade including this species can be unambiguously referred to Phymatolithon as circumscribed morphologically by Woelkerling \& Irvine (1986). This contrasted with the New Zealand sample identified by Broom et al. (2008) as P. repandum (EF628216/ DQ167883), which was placed in the Mesophyllum/ Synarthrophyton clade (Fig. 3). Phymatolithon purpureum (conspecific with the unidentified Hapalidiaceae LB0005 from Atlantic France sequenced by Bittner et al., 2011) belongs to the Phymatolithon clade, and represents a different, unidentified, genus. In the case of Lithothamnion 
corallioides, the type specimen did not yield DNA sequences, but it was used to confirm the morphological identification of the specimens used in the present work, which included topotype material and which agreed also with the descriptions by Adey \& McKibbin (1970) and Irvine \& Chamberlain (1994), allowing reliable identification.

Three taxa included in the present study were recovered as polyphyletic: Lithophyllum margaritae, Mesophyllum erubescens and Neogoniolithon brassica-florida (Fig. 3). In the case of L. margaritae, a previous taxonomic reassessment based on morphological characteristics and examination of type material (Riosmena-Rodríguez et al., 1999) suggested the presence of only one species in the Gulf of California and placed six of the names previously used in synonymy with $L$. margaritae. The present study showed that there are at least two different Lithophyllum entities forming rhodoliths in the Gulf of California and sharing the morphology of L. margaritae sensu lato, pointing to the need for a new taxonomic reassessment of the genus in this area. Further studies should include sequences of type material and new collections because both species co-occur at the type locality (Bay of La Paz, Baja California Sur, Mexico). The specimen identified herein as Mesophyllum erubescens was collected in the Canary Islands, about $4000 \mathrm{~km}$ away from the type locality (Fernando de Noronha, Brazil), questioning whether this specimen genuinely belongs to that taxon. In this study the name Mesophyllum erubescens is therefore used sensu lato, as the morphology of the specimen used herein agrees with descriptions in the literature (Keats \& Chamberlain, 1994; Horta et al., 2011). However, further study is necessary to assess features that may unambiguously identify any of the entities commonly referred to $M$. erubescens sensu lato. The same considerations apply to Neogoniolithon brassica-florida, for which the type locality is Algoa Bay in South Africa (Guiry \& Guiry, 2014), while the specimens in the present study are from Cadiz, Spain (14 $000 \mathrm{~km}$ away).

In conclusion, based on molecular analyses, the rhodolith-forming habit was characteristic of some phylogenetic lineages but in a species of Lithophyllum it appears to be the result of environmental influences. The lack of correlation between morphological identification, which includes the rhodolith habit, and genetic relationships, will require taxonomic revision of Lithophyllum margaritae and L. incrustans/dentatum. Given the ecological and commercial importance of rhodoliths, the identification of several cryptic species and the lack of taxonomic value for the rhodolith habit in some species of the genus Lithophyllum, we need to further explore species boundaries using information from type material and test the stability of morphological characters used to identify species. Molecular identification of Phymatolithon calcareum and
Lithothamnion corallioides was confirmed using sequences from the epitype of $P$. calcareum and from topotype specimens of $L$. corallioides, which is particularly useful given the ecological significance of these species and the legislative provisions for their conservation in Europe.

\section{Acknowledgements}

JHK was supported by a $\mathrm{PhD}$ scholarship from CONACyT-211950 (National Council for Science and Technology, Mexico) and SEP (Secretariat for Public Education, Mexico). Financial support was received from the Marine Institute (Ireland) as part of the National Marine Biodiscovery Programme (Beaufort Award for Marine Biodiscovery to the National University of Ireland, Galway), from the European Community through the FP6-funded project HIPPOCRATES (NMP3-CT-2003-505758), and from the National University of Ireland, Galway through the Thomas Crawford Award. Collection trips in the Gulf of California were funded by CONACyT, CONABIO and FMCN. FR is grateful to the Università Politecnica delle Marche for financial support (Contributo Ricerca Scientifica Fondi Ateneo 2011). VP is supported by Xunta de Galicia (Axudas de apoio á etapa inicial de formación posdoutoral do Plan I2C, 2012) and Spain's Ministerio de Educación (Programa Nacional de Movilidad de Recursos Humanos, 2008-2011). Jacques Grall, Charmaine Blake, Meadhbh Moriarty, Ricardo Bermejo Lacida, Julia Nunn, Ignacio Bárbara, José Castillo, Alejandra Sanchez, Michael Guiry and Niamh Nolan are gratefully acknowledged for collection of samples and/or assistance in the field. We thank Jo Wilbraham at BM for assistance with obtaining specimens on loan and Pierce Lalor for his help with the SEM images. Michael Guiry, Wendy Nelson and Aki Kato provided useful information and stimulating discussions. Special thanks to the anonymous reviewers and editor Professor Juliet Brodie for their comments and suggestions. JHK extends special gratitude to the Irish Seaweed Research Group and the Smithsonian Institution.

\section{Supplementary information}

The following supplementary material is accessible via the Supplementary Content tab on the article's online page at http://dx.doi.org/10.1080/09670262.2014.984347

Supplementary Table 1. List of additional SSU and $p s b$ A sequences used in this study.

Supplementary Table 2. Collection information and information used for identification in the present study.

Supplementary Figs 25-28. Morphology and reproductive characteristics of some rhodolith specimens of Lithophyllum sp. 3 and Phymatolithon purpureum. Fig. 25. Lithophyllum sp. 1 morphology (E153). Fig. 26. Lithophyllum sp. 3, conceptacle shape (SEM) 
(specimen E153). Fig. 27. P. purpureum E28, morphology. Fig. 28. P. purpureum E28, pore ring in the conceptacle aperture distinctive of this species. For collection details see Table 1. Scale bars: Figs 22, 24, 10 mm; Fig. 23, $250 \mu \mathrm{m}$; Fig. 25, $160 \mu \mathrm{m}$.

Supplementary Figs 29-34. Anatomical details of some rhodolith-forming species studied. Fig. 29. Lithophyllum sp. 1 (E27) with secondary pit connection (arrow). Fig. 30. Lithophyllum sp. 1 (E35) with secondary pit connection (arrow). Fig. 31. Mesophyllum erubescens (E36). Fig. 32. Neogoniolithon spectabile (E93) showing rectangular epithallial cells. Fig. 33. Unidentified Hapalidiaceae (E58) showing a cell fusion (roundheaded arrow). Fig. 34. Unidentified Hapalidiaceae (E58) showing flared epithallial cells (arrowhead). For collection details see Table 1. Scale bars: Figs $29-34,10 \mu \mathrm{m}$.

\section{References}

AdeY, W.H. \& McKibBin, D.L. (1970). Studies on the maërl species Phymatolithon calcareum (Pallas) nov. comb. and Lithothamnium corallioides Crouan in the Ria de Vigo. Botanica Marina, 13: 100106.

Aguirre, J., Perfectti, F. \& Braga, J.C. (2010). Integrating phylogeny, molecular clocks and the fossil record in the evolution of coralline algae (Corallinales and Sporolithales, Rhodophyta). Paleobiology, 36: 519-533.

Bahía, R.G., Amado-Filho, G., Maneveldt, G.W., Adey, W. H., Johnson, G., Marins, B.V. \& Longo, L.L. (2014). Sporolithon tenue sp. nov. (Sporolithales, Corallinophycidae, Rhodophyta): a new rhodolith-forming species from the tropical southwestern Atlantic. Phycological Research, 62: 44-54.

Bailey, J.C. \& ChaPMAN, R.L. (1996). Evolutionary relationships among coralline red algae (Corallinaceae, Rhodophyta) determined by $18 \mathrm{~S}$ rRNA gene sequence analysis. In Cytology, Genetics and Molecular Biology of Algae (Chaudhary, B. R., Agrawal, S. B., editors), 363-376. SPB Academic Publishing, Amsterdam.

BAiley, J.C. \& ChaPMAN, R.L. (1998). A phylogenetic study of the Corallinales (Rhodophyta) based on nuclear small-subunit rRNA gene sequences. Journal of Phycology, 34: 692-705.

Bailey, J.C., Gabel, J.E. \& Freshwater, D.W. (2004). Nuclear 18S rRNA gene sequence analyses indicate that the Mastophoroideae (Corallinaceae, Rhodophyta) is a polyphyletic taxon. Phycologia, 43: 3-12.

Basso, D., Rodondi, G. \& Mari, M. (2004). A comparative study between Lithothamnion minervae and the type material of Millepora fasciculata (Corallinales, Rhodophyta). Phycologia, 43: 215-223.

Bittner, L., Payri, C., Maneveldt, G., Couloux, A., Cruaud, C., De Reviers, B. \& Le Gall, L. (2011). Evolutionary history of the Corallinales (Corallinophycidae, Rhodophyta) inferred from nuclear, plastidial and mitochondrial genomes. Molecular Phylogenetics and Evolution, 61: 697-713.

Bressan, G. \& BABBINI, L. (2003). Biodiversità marina delle coste Italiane: Corallinales del Mar Mediterraneo: guida alla deteminazione. Biologia Marina Mediterranea, 10: 1-237.

Broom, J.E.S., Hart, D.R., Farr, T.J., Nelson, W.A., Neill, K.F., Harvey, A.S. \& Woelkerling, W.J. (2008). Utility of $p s b$ A and nSSU for phylogenetic reconstruction in the Corallinales based on New Zealand taxa. Molecular Phylogenetics and Evolution, 46: 958-973.

САвIOCH, J. (1969). Les fonds de maërl de la Baie de Morlaix et leur peuplement végétal. Cahiers de Biologie Marine, 10: 139-161.

Crouan, P.L. \& Crouan, H.M. (1867). Florule du Finistère. Friedrich Klincksieck \& J.B. et A. Lefournier. Paris \& Brest.
Foslie, M. (1900). New or critical calcareous algae. Det Kongelige Norske Videnskabers Selskabs Skrifter 1899 (5): 1-34.

FosLIE, M. (1906). Algologiske Notiser II. Det Kongelige Norske Videnskabers Selskabs Skrifter 1906 (2): 1-28.

FosTER, M.S. (2001). Rhodoliths: between rocks and soft places. Journal of Phycology, 37: 659-667.

Gabrielson, P.W., Miller, K.A. \& Martone, P. (2011). Morphometric and molecular analyses confirm two distint species of Calliarthron (Corallinales, Rhodophyta), a genus endemic to the northeast Pacific. Phycologia, 50: 298-316.

GuIRY, M.D. \& GuIRY, G.M. (2014). AlgaeBase. World-wide electronic publication, National University of Ireland, Galway. http:// www.algaebase.org; searched on 06 June 2014.

Hall-Spencer, J., White, N., Gillespie, G., Gillham, K. \& Foggo, A. (2006). Impact of fish farms on maerl beds in strongly tidal areas. Marine Ecology Progress Series, 326: 1-9.

Hall-Spencer, J.M., Kelly, J. \& Maggs, C.A. (2010). Background document for maerl. OSPAR Commission, 491/2010, $36 \mathrm{pp}$. ISBN 978-1-907390-32-6. www.ospar.org/documents\%5Cdbase\%5Cpu blications \%5CP00491 maerl.pdf.

Harvey, A.S. \& WoelKerLing, W.J. (2007). A guide to nongeniculate coralline red algal (Corallinales, Rhodophyta) rhodolith indentification. Ciencias Marinas, 33: 411-426.

Harvey, A.S., Broadwater, S.T., WoelKerling, W.J. \& Mitrovski, P.J. (2003). Choreonema (Corallinales, Rhodophyta): 18S rDNA phylogeny and resurrection of the Hapalidiaceae for the subfamilies Choreonematoideae, Australithoideae, and Melobesioideae. Journal of Phycology, 39: 988-98.

HERNANDEZ-KANTUN, J.J. (2013). Taxonomy, molecular biodiversity and ecology of coralline algae (Corallinales: Rhodophyta), with special emphasis on maerl-forming species. PhD thesis, National University of Ireland, Galway.

Hind, K.R., Gabrielson, P.W., Lindstrom, S.C. \& Martone, P.T. (2014). Misleading morphologies and the importance of sequencing type specimens for resolving coralline taxonomy (Corallinales, Rhodophyta): Pachyarthron cretaceum is Corallina officinalis. Journal of Phycology, 50: 760-764.

Horta, A.P., Scherner, F., Bouzon, Z.L., Riosmena-Rodriguez, R. \& OliveirA, E.U. (2011). Morphology and reproduction of Mesophyllum erubescens (Foslie) Me. Lemoine (Corallinales, Rhodophyta) from Southern Brazil. Revista Brasileira de Botanica, 34: 125-134.

HuelsenBeCK, J.P. \& Ronquist, F. (2001). MrBayes: Bayesian inference of phylogeny. Bioinformatics, 17: 754-755.

Irvine, L.M. \& Chamberlain, Y.M. (1994). Seaweeds of the British Isles. Vol. 1. Rhodophyta Part 2B Corallinales, Hildenbrandiales. HMSO, London.

JoвB, G. (2008). TREEFINDER version of October 2008, Munich. Distributed by the author at www.treefinder.de.

Johansen, H.W. (1981). Coralline Algae, A First Synthesis. Boca Raton, FL: CRC Press.

Kamenos, N.A., Moore, P.G. \& Hall-Spencer, J.M. (2004).

Nursery-area function of maerl grounds for juvenile queen scallops Aequipecten opercularis and other invertebrates. Marine Ecology Progress Series, 274: 183-189.

Kato, A., Baba, M. \& Suda, S. (2011). Revision of the Mastophoroideae (Corallinales, Rhodophyta) and polyphyly in nongeniculate species widely distributed on Pacific coral reefs. Journal of Phycology, 47: 662-672.

Kato, A., BABA, M. \& SudA, S. (2013). Taxonomic circumscription of heterogeneous species Neogoniolithon brassica-florida (Corallinales, Rhodophyta) in Japan. Phycological Research, 61: $15-26$.

Keats, D.W. \& Chamberlain, Y.M. (1994). Two melobesioid coralline algae (Rhodophyta, Corallinales): Mesophyllum erubescens (Foslie) Lemoine and Mesophyllum funafutiense (Foslie) Verheij from Sodwana Bay, South Africa. South African Journal of Botany, 60: 175-190.

Konar, B., Riosmena-Rodriguez, R. \& IKen, K. (2006). Rhodolith bed: a newly discovered habitat in the North Pacific Ocean. Botanica Marina, 49: 355-359. 
Le Gall, L. \& SAunders, G.W. (2007). A nuclear phylogeny of the Florideophyceae (Rhodophyta) inferred from combined EF2, small subunit and large subunit ribosomal DNA: Establishing the new red algal subclass Corallinophycidae. Molecular Phylogenetics and Evolution, 43: 1118-1130.

Le Gall, L., Payri, C.E., Bittner, L.E. \& Saunders, G.W. (2010). Multigene phylogenetic analyses support recognition of the Sporolithales, ord. nov. Molecular Phylogenetics and Evolution, 54: 302-305.

Littler, D.S. \& LitTler, M.M. (2000). Caribbean Reef Plants: An Identification Guide to the Reef Plants of the Caribbean, Bahamas, Florida and Gulf of Mexico. Offshore Graphics, Washington, DC.

Mendoza, M.L. \& CABioch, J. (1998). Étude comparée de la reproduction de Phymatolithon calcareum (Pallas) Adey \& McKibbin et Lithothamnion corallioides (P. \& H. Crouan) P. \& H. Crouan (Corallinales, Rhodophyta), et reconsidérations sur le définition des genres. Canadian Journal of Botany, 76: 1433-1445.

Milazzo, M., Rodolfo-Metalpa, R., Bin San Chan, V., Fine, M., Cinzia, A., Thiyagarajan, V., Hall-Spencer, J.M. \& Chemello, R (2014). Ocean acidification impairs vermetid reef recruitment. Scientific Reports, 4: 4189.

Pardo, C., Lopez, L., Peña, V., Hernandez-Kantun, J., Le Gall, L., Barbara, I. \& BARreiro, R. (2014). A Multilocus species delimitation reveals a striking number of species of coralline algae forming maerl in the OSPAR maritine area. PLoS ONE, 9(8): e104073.

Patterson, C. (1988). Homology in classical and molecular biology. Molecular Biology and Evolution, 5: 603-605.

Peña, V. \& BÁrbarA, I. (2008). Maërl community in the northwestern Iberian peninsula: a review of floristic studies and longterm changes. Aquatic Conservation: Marine and Freshwater Ecosystems, 18: 339-366.

Peña, V., Barreiro, R., Hall-Spencer, J.M. \& Grall, J. (2013). Lithophyllum spp. form unusual maerl beds in the North East Atlantic: the case study of L. fasciculatum (Lamarck) Foslie, 1898, in Brittany. An Aod - Les cahiers Naturalistes de L'Observatoire Marin, 2: 11-21.

Peña, V., Adey, W.H., Riosmena-Rodriguez, R., Yung, M-Y., Choi, H-G., Afonso-Carrillo, J. \& BÁrbara, I. (2011). Mesophyllum sphaericum sp. nov. (Corallinales, Rhodophyta): a new maërlforming species from the northeast Atlantic. Journal of Phycology, 47: 911-927.

Peña, V., Bárbara, I., Grall, J., Maggs, C.A. \& Hall-Spencer, J.M. (2014a). The diversity of seaweeds on maerl in the NE Atlantic. Marine Biodiversity, 44: 533-551. doi:10.1007/s12526014-0214-7.

Peña, V., Hernandez-Kantun, J.J., Grall, J., Pardo, C., Lopez, L., Bárbara, I., Le Gall, L. \& Barreiro, R. (2014b). Detection of gametophytes in the maerl-forming species Phymatolithon calcareum (Melobesioideae, Corallinales) assessed by DNA barcoding. Cryptogamie Algologie, 35: 15-25.

PosADA, D. (2008). jModelTest: phylogenetic model averaging. Molecular Biology and Evolution, 25: 1253-1256.

Rambaut, A. \& DRummond, A.J. (2007). Tracer v1.4, available from http://beast.bio.ed.ac.uk/Tracer.

Riosmena-Rodríguez, R., Woelkerling W.J. \& Foster, M.S. (1999). Taxonomic reassessment of rhodolith-forming species of Lithophyllum (Corallinales, Rhodophyta) in the Gulf of California, México. Phycologia, 38: 401-417.

Riosmena-Rodríguez, R., Lopez-CAlderon, J.M., MarianoMelendez, E., Sanchez-Rodriguez, A. \& Fernandez-Garcia, C. (2012). Size and distribution of rhodolith beds in the Loreto Marine Park: their role in coastal processes. Journal of Coastal Research, 28: 255-60.
Rix, L. N., Burdett, H. L. \& Kamenos, N.A. (2012). Irradiancemediated dimethylsulphoniopropionate (DMSP) responses of coralline red algae. Estuarine, Coastal and Shelf Science, 96: 268-272.

SAunders, G.W. \& Kraft, G.T. (1994). Small-subunit rRNA gene sequences from representatives of selected families of the Gigartinales and Rhodymeniales (Rhodophyta). I. Evidence for the Plocamiales ord. nov. Canadian Journal of Botany, 72: 1250-1263.

Silvestro, D. \& Michalak, I. (2011). RAxMLGUI: a graphical front-end for RAxML. Available at https://sites.google.com/site/ raxmlgui/.

Tamura, K., Peterson, D., Peterson, N., Stecher, G., Nei, M. \& KumAR, S. (2011). MEGA5: Molecular evolutionary genetics analysis using maximum likelihood, evolutionary distance, and maximum parsimony methods. Molecular Biology and Evolution, 28: 2731-2739.

Teichert, S., Woelkerling, W., Rüggeberg, A., Wisshak, M., Piepenburg, D., Meyerhöfer, M., Form, A., Büdenbender, J. \& Freiwald, A. (2012). Rhodolith beds (Corallinales, Rhodophyta) and their physical and biological environment at $80^{\circ} 31^{\prime} \mathrm{N}$ in Nordkappbukta (Nordaustlandet, Svalbard Archipelago, Norway). Phycologia, 51: 371-390.

THIERs, B. (2014). Index Herbariorum: A Global Directory of Public Herbaria and Associated Staff. New York Botanical Garden's Virtual Herbarium. http://sweetgum.nybg.org/ih/.

Tomás, S., Aguirre, J., Braga, C.J. \& Martín-Closas, C. (2007). Late Hauterivian coralline algae (Rhodophyta, Corallinales) from the Iberian Chain (E Spain). Taxonomy and the evolution of multisporangial reproductive structures. Facies, 53: 79-95.

Verbruggen, H. \& Kooistra, W.C.F. (2004). Morphological characterization of lineages withing the calcified tropical seaweed genus Halimeda (Bryopsidales, Chlorophyta). European Journal of Phycology, 39: 213-228.

Verbruggen, H., Maggs, C., Saunders, G., Le Gall, L., Yoon, H. \& De Clerck, O. (2010). Data mining approach identifies research priorities and data requirements for resolving the red algal tree of life. BMC Evolutionary Biology, 10: 16.

Vidal, R., Meneses, I. \& Smith, M. (2008). Phylogeography of the genus Spongites (Corallinales, Rhodophyta) from Chile. Journal of Phycology, 44: 173-182.

Walker, R.H., Brodie, J., Russell, S., Irvine, L.M. \& Orfanidis, S. (2009). Biodiversity of coralline algae in the northeastern Atlantic including Corallina caespitosa sp. nov. (Corallinoideae, Rhodophyta). Journal of Phycology, 45: 287-297.

Woelkerling, W.J. (1988). The Coralline Red Algae: an Analysis of the Genera and Subfamilies of Nongeniculate Corallinaceae. British Museum (Natural History) \& Oxford University Press, London \& Oxford.

Woelkerling, W.J. \& Irvine, L.M. (1986). The neotypification and status of Phymatolithon (Corallinaceae, Rhodophyta). British Phycological Journal, 21: 55-80.

Woelkerling, W.J. \& Lamy, D. (1998). Non-geniculate Coralline Red Algae and the Paris Museum: Systematics and Scientific History. Publications Scientifiques du Muséum/ADAC, Paris.

Yabur-Pacheco, R. \& Riosmena-Rodríguez, R. (2006). Rhodolith bed composition in the southwestern Gulf of California, Mexico. The Nagisa World Congress, 1: 37-47.

Yoon, H.S., Hackett, J.D. \& Bhattacharya, D. (2002). A single origin of the peridinin- and fucoxanthin-containing plastids in dinoflagellates through tertiary endosymbiosis. Proceedings of the National Academy of Sciences USA, 99: 11724-11729. 